споживатися на самому підприємстві, бути внутрішнім ресурсом виробництва.

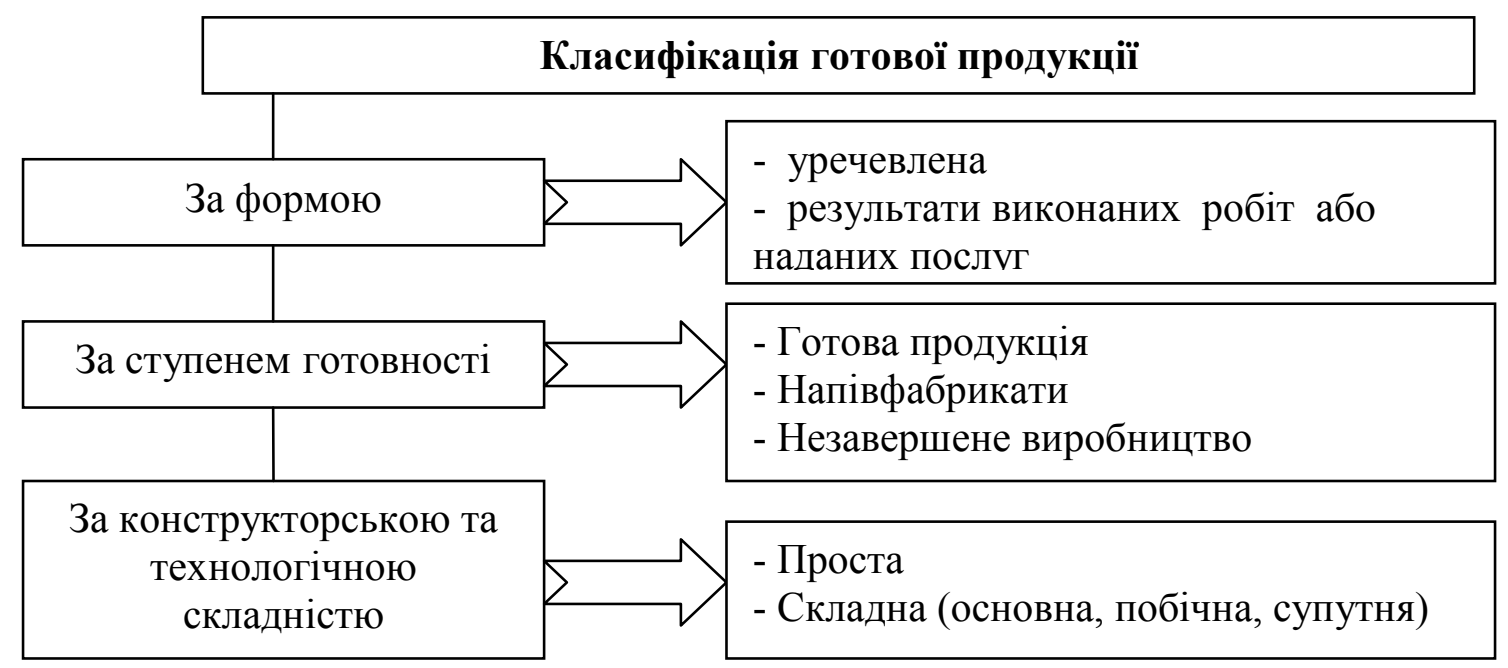

Рис. 1. Класифікація готової продукції за іїі характером

Джерело: складено автором на основі $[3,4,6]$.

Література:

1. Положення (стандарт) бухгалтерського обліку № 9 “Запаси”, затверджене наказом Міністерства фінансів України від №246 від 20.10.1999p., iз змінами та доповненнями. [Електронний ресурс] - Режим доступу: http://www.minfin.gov.ua

2. Амбівалентність і мімікрія облікової теорії [Текст] : монографія / Г. П. Журавель, В. Б. Клевець, В. М. Олійничук, П. Я. Хомин ; за ред. П. Я. Хомина. - Тернопіль : ТНЕУ, 2016. - 474 с.

3. Бухгалтерський фінансовий облік [текст]: підручник для студентів спеціальності “Облік і аудит” вищих навчальних закладів [Ф.Ф.Бутинець та ін.]; під. заг. ред. [і з передм.] Ф.Ф. Бутинця. - 8-ме вид., доп. і перероб. - Житомир: ПП "Рута", 2013. - 912 с.

4. Сопко В. В. Бухгалтерський облік : [навч. посібн.] / В. В. Сопко. - 3-тє вид., перероб. і доп. - К. : КНЕУ, 2002. - 578 с.

5. Ткаченко Н.M. Бухгалтерський фінансовий облік на підприємствах України / Н.М. Ткаченко. - К. : А.С.К., 2011. - 784 с.

6. Швець В.Г. Теорія бухгалтерського обліку: підручник; [4-те вид., перероб. і доп.] / В.Г. Швець. - К.: Знання, 2015. - 572 с.

Статья відправлена: 17.03.2017 p.

(C) Семенюта A.B.

\title{
ЦИТ: иа117-012
}

DOI: 10.21893/2415-7538.2016-05-1-012

Копанчук К.В.

МЕТОДИЧНІ ОСНОВИ АНАЛІЗУ РОЗРАХУНКІВ 3 ПОКУПЦЯМИ ТА ЗАМОВНИКАМИ

Київький національний університет імені Тараса Шевченка 


\title{
METHODICAL BASIS OF ANALYSIS OF SETTLEMENTS WITH BUYERS
} AND CUSTOMERS

\author{
Taras Shevchenko National university of Kyiv
}

Анотація. В статті розглянуто методику аналізу дебіторської заборгованості за товари, роботи, послуги як основу аналізу розрахунків 3 покупцями та замовниками на підприємстві. Визначено існуючі переваги в сучасних методиках аналізу розрахунків з покупчями та замовниками. Обгрунтовано необхідність проведення аналізу дебіторської заборгованості за товари, роботи, послуги для прийняття ефективних управлінських рішень щзодо розрахунків з покупиями та замовниками.

Ключові слова: методика, аналіз, дебіторська заборгованість, розрахунки з покупиями та замовниками, управління.

Abstract. In this paper we describe the method of analysis of receivable for goods, work and services as the basis of analysis of settlements with buyers and customers in the enterprise. We identify existing benefits of modern methods of analysis of settlements with buyers and customers. We describe necessity of the analysis of receivable for goods, works and services for effective management decisions regarding settlements with buyers and customers.

Key words: methodology, analysis, receivables, settlements with buyers and customers, management.

Вступ. В сучасних умовах економічного стану суспільства аналіз та управління дебіторською заборгованістю за товари, роботи, послуги позиціонуються провідними факторами забезпечення фінансової стійкості підприємства, що пояснюється кризою неплатежів. Наявний стан аналітичного забезпечення для прийняття ефективних та обгрунтованих управлінських рішень не $\epsilon$ достатнім. Крім того, існує загроза подальшого посилення негативних тенденцій у обсягах дебіторської заборгованості та виникнення такого небажаного ії виду як безнадійна.

Основний текст. Аналіз стану розрахунків з покупцями та замовниками необхідно здійснювати для формування інформації щодо стану дебіторської заборгованості за товари, роботи, послуги. Існування дебіторської заборгованості у складі активів балансу свідчить про відволікання або навіть капіталізацію грошових коштів підприємства. Специфіка проявів і наслідків існування дебіторської заборгованості спонукає дослідити методику аналізу дебіторської заборгованості за товари, роботи, послуги.

Методика аналізу дебіторської заборгованості включає наступні етапи: вибір політики кредитування контрагентів; розрахунок загальної необхідності відволікання готівки у дебіторську заборгованість; визначення складу i динаміки дебіторської заборгованості; аналіз оборотності дебіторської заборгованості; аналіз приросту дебіторської заборгованості; розрахунок наданих знижок; класифікація дебіторської заборгованості, виходячи 3 іi ліквідності; модифікувати методику оцінки, виходячи $з$ нормативу ліквідності та терміну погашення дебіторської заборгованості; схематичне відтворення 
системи контролю та аналізу; дослідження можливих варіантів рефінансування; постійний моніторинг дебіторської заборгованості. Розглянута методика аналізу дебіторської заборгованості за товари, роботи, послуги містить сучасні і дієві складові аналізу та оцінки дебіторської заборгованості, які вимагають більшої деталізації обліку дебіторської заборгованості за товари, роботи, послуги в системі управління підприємством. До методики включено методи оцінки критичної величини дебіторської заборгованості за товари, роботи, послуги 3 врахуванням іiі ліквідності, операційного циклу, а також методику аналізу приросту дебіторської заборгованості. Запропонована методика аналізу дебіторської заборгованості за товари, роботи, послуги створює передумови для ведення активної політики управління розрахунками 3 покупцями та замовниками, яка передбачає цілеспрямовану дію на умову реалізації товарів 3 відстроченням оплати (політика кредитування покупців).

Розглянемо ще один варіант методики аналізу дебіторської заборгованості за товари, роботи, послуги, запропоновану Кияшко О.М. (рис 1). Аналіз показників, які характеризують стан дебіторської заборгованості за певний період, дає змогу визначити основні завдання політики управління дебіторською заборгованістю. Основні показники оцінки стану та якості дебіторської заборгованості наведено у таблиці 1.

Таблиця 1.

Аналітичні показники дебіторської заборгованості за товари, роботи, послуги

\begin{tabular}{|c|c|c|}
\hline Показник & Методика розрахунку & Зміст \\
\hline $\begin{array}{l}\text { Коефіцієнт оборотності } \\
\text { дебіторської } \\
\text { заборгованості за } \\
\text { товари, роботи, } \\
\text { послуги (Коб) }\end{array}$ & $\begin{array}{c}\text { Коб = ЧДр / Дз, } \\
\text { де ЧДр -чистий дохід від } \\
\text { реалізації продукції; } \\
\text { Дз - дебіторська заборгованість } \\
\text { (середня за аналізований } \\
\text { період) }\end{array}$ & $\begin{array}{c}\text { Показує скільки разів оберталася } \\
\text { дебіторська заборгованість за } \\
\text { аналізований період }\end{array}$ \\
\hline $\begin{array}{c}\text { Період погашення } \\
\text { (Обдн) }\end{array}$ & $\begin{array}{c}\text { Обдн }=360 / \text { Коб = (Дз/ Вp) }{ }^{*} \text { Т, } \\
\text { де Т - тривалість обігу } \\
\text { дебіторської заборгованості }\end{array}$ & $\begin{array}{c}\text { Показує скільки днів потрібно } \\
\text { для одного обороту. Що } \\
\text { триваліше період погашення, то } \\
\text { вище ризик її неповернення }\end{array}$ \\
\hline $\begin{array}{l}\text { Частка дебіторської } \\
\text { заборгованості за } \\
\text { товари, роботи, } \\
\text { послуги в загальному } \\
\text { обсязі оборотних } \\
\text { коштів (Удз) }\end{array}$ & $\begin{array}{c}\text { Удз = Дз / Обз * 100, } \\
\text { де Обз - загальний обсяг } \\
\text { оборот- них коштів }\end{array}$ & $\begin{array}{c}\text { Показує частку дебіторської } \\
\text { заборгованості в загальному } \\
\text { обсязі оборотних коштів } \\
\text { підприємства. Що вище цей } \\
\text { показник, то менш мобільна } \\
\text { структура майна підприємства }\end{array}$ \\
\hline $\begin{array}{c}\text { Частка сумнівної в } \\
\text { складі дебіторської } \\
\text { заборгованості (Усз) }\end{array}$ & $\begin{array}{c}\text { Усз }=\mathrm{C}_{3} / \text { Дз } * 100, \text { де С3 - } \\
\text { сумнівна заборгованість }\end{array}$ & $\begin{array}{c}\text { Характеризує якість дебіторської } \\
\text { заборгованості. Тенденції до } \\
\text { росту показника свідчать про } \\
\text { зниження ліквідності } \\
\text { підприємства }\end{array}$ \\
\hline
\end{tabular}

Джерело: [6].

Ця методика дасть змогу виявити нереалізовані вигоди підприємства, зміцнити його фінансовий стан, збільшити стійкість та ефективно контролювати грошові надходження в погашення дебіторської заборгованості за товари, роботи, послуги, сприятиме збереженню власного капіталу 


\section{підприємства.}

\begin{tabular}{|c|c|c|}
\hline 1 етап & \multirow{2}{*}{$\begin{array}{c}\text { Визначення } \\
\text { об’єкта аналізу } \\
\text { Формування } \\
\text { мети аналізу }\end{array}$} & \multirow{2}{*}{$\begin{array}{c}\text { Дебіторська заборгованість за товари, роботи, послуги } \\
\text { Проведення оцінки рівня та складу дебіторської } \\
\text { заборгованості підприємства, а також сум вилучених } 3 \\
\text { обігу коштів }\end{array}$} \\
\hline & & \\
\hline & $\begin{array}{c}\text { Постановка } \\
\text { завдання }\end{array}$ & $\begin{array}{l}\text { - Вивчення причин виникнення дебіторської } \\
\text { заборгованості. } \\
\text { - Оцінка покупців з погляду надійності й важливості. - } \\
\text { - 3’ясування причин прострочення платежів. } \\
\text { - Контроль за своєчасністю погашення дебіторської } \\
\text { заборгованості. } \\
\text { - Оцінка ефективності управління дебіторською } \\
\text { заборгованістю. } \\
\text { - Формування кредитної політики підприємства }\end{array}$ \\
\hline 2 етап & $\begin{array}{c}\text { Збір та } \\
\text { підготовка } \\
\text { джерел } \\
\text { інформації, } \\
\text { необхідних для } \\
\text { аналізу }\end{array}$ & $\begin{array}{l}\text { - Форма № } 1 \text { «Баланс (Звіт про фінансовий стан)». - } \\
\text { - Форма № } 2 \text { «Звіт про фінансові результати (Звіт про } \\
\text { сукупний дохід)». } \\
\text { - Форма № } 5 \text { «Примітки до річної фінансової } \\
\text { звітності». } \\
\text { - Звіт про дебіторську та кредиторську заборгованість } \\
\text { підприємства. } \\
\text { - Аналітична інформація відділу продажів }\end{array}$ \\
\hline 3 етап & \multirow{2}{*}{$\begin{array}{c}\text { Кількісний } \\
\text { аналіз } \\
\text { дебіторської } \\
\text { заборгованості }\end{array}$} & \multirow{2}{*}{$\begin{array}{l}\text { - Горизонтальний і вертикальний аналіз. } \\
\text { - Дослідження динаміки дебіторської заборгованості. } \\
\text { - Аналіз показників, що характеризують стан } \\
\text { дебіторської заборгованості (коефіцієнт відволікання } \\
\text { обігових коштів у дебіторську заборгованість, } \\
\text { коефіцієнт оборотності, середній період погашення, } \\
\text { частка у загальному обсязі поточних активів, частка } \\
\text { сумнівної дебіторської заборгованості тощо). }\end{array}$} \\
\hline & & \\
\hline
\end{tabular}

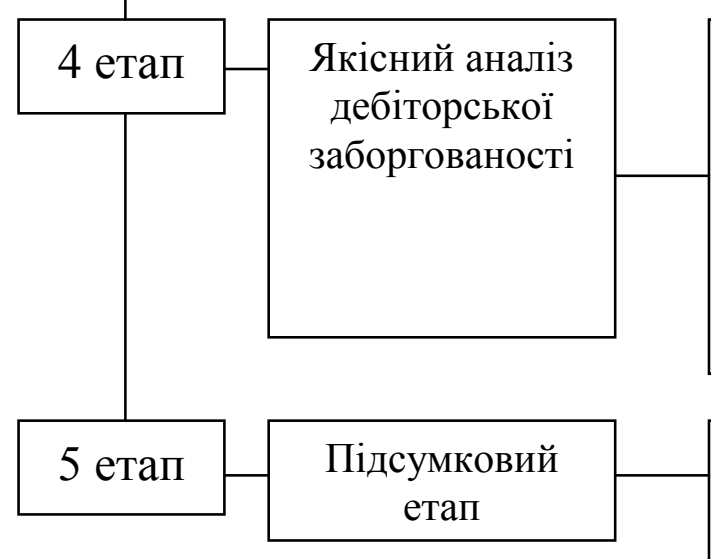

- Встановлення рейтингу важливості окремих складових дебіторської заборгованості.

- Визначення асортиментних груп товарів, на які припадає найбільша частка у структурі дебіторської заборгованості.

- Виявлення в межах асортиментних груп товарів стратегічно важливих дебіторів компанії

Прийняття відповідних управлінських рішень, які дадуть змогу зменшити рівень дебіторської заборгованості

Рис 1. Напрями і види аналізу дебіторської заборгованості за товари, роботи, послуги.

Джерело: [5]. 
Висновки. В статті розглянуто методику аналізу дебіторської заборгованості за товари, роботи, послуги. Досліджено необхідність проведення ефективного аналізу. Також варто зазначити, що правильний та своєчасний аналіз дебіторської заборгованості дозволяє оцінити ефективність і збалансованість товарного кредиту і надання знижок покупцям, визначає сфери, в яких необхідно докласти додаткових зусиль для повернення боргів, дає базу для створення резерву сумнівних боргів, сприяє прогнозуванню надходження коштів.

Література:

1. Базилевич В., Базилевич К. Ринкова економіка - К.: Знання, 2006.-168 с.

2. Гнатенко Є.П., Лебедик А.М. Сучасні методики аналізу дебіторської заборгованості/ Гнатенко С.П., Лебедик А.М.//Електронне видання «Молодий вчений», № 11 (38) - 2016 p.

3. Голубнича Г.П. Економічний аналіз: навч. посібник / Г.П.Голубнича, Л.І.Панасенко. - К.: КНУ імені Тараса Шевченка, 2009. - 290с.

4. Golubnicha G., Melnik T. Фінансова звітність та первинна документація українських підприємств при застосуванні МСФЗ//Вісник Киівського національного університету ім. Тараса Шевченка. Серія: Економіка. 2013. № 150. С. 29-34.

5. Кияшко О.М. Облік та аналіз дебіторської заборгованості в системі управління підприємством : автореф. дис.канд. екон. наук : спец. 08.00.09 «Бухгалтерський облік, аналіз та аудит (за видами діяльності)» / О.М. Кияшко. - K., 2011. -23 c.

6. Сарапіна О.А., Кірілкіна О.Є. Методологічні основи аналізу дебіторської заборгованості./ Сарапіна О.А., Кірілкіна О.С.//Наукове фахове видання «Глобальні та національні проблеми економіки» - Вип. 3. - 2015 р., с. 865-868. Стаття відправлена: 11.03.2017

(c) Копанчук К.В.

\author{
ЦИТ: иа117-023
}

DOI: 10.21893/2415-7538.2016-05-1-023

Рак O.B.

ШЛЯХИ ОПТИМІЗАЦІЇ АНАЛІТИЧНОГО ОБЛІКУ РОЗРАХУНКІВ 3 ПОСТАЧАЛЬНИКАМИ ТА ПІДЯДНИКАМИ

Київський начіональний університет імені Тараса Шевченка

Rak O.V. DESTINATIONS IMPROVEMENT OF ACCOUNTING OF PAYMENTS TO SUPPLIERS AND CONTRACTORS

Анотація. У статті розглянуто специффіку економічних взаємовідносин та розрахункових операцій з постачальниками та підрядниками. У ході дослідження було виявлено проблемні питання обліку розрахунків 3 постачальниками та підрядниками, зокрема, відсутність аналітики заборгованості за постачальниками та розмежування між поточною 